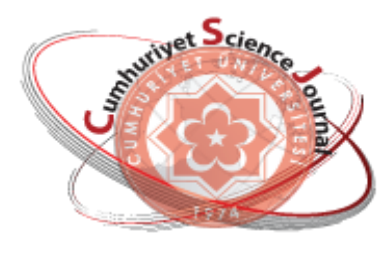

e-ISSN: $2587-246 X$

ISSN: $2587-2680$

\section{Cuculanoiy ot Seionee Journal $\operatorname{csg}$}

Cumhuriyet Sci. J., Vol.40-3 (2019) 595-601

\title{
Determination of the annual effective dose distribution due to cosmic ray exposure of the Eastern Black Sea Region, Turkey
}

\author{
Cafer Mert YEŞILLKANAT
}

Science Teaching Department, Artvin Çoruh University, Artvin, Turkey

\begin{abstract}
In this study, annual effective dose rate distribution due to cosmic radiation, which constitutes an important part of natural radiation, was mapped in $200 \times 200 \mathrm{~m}^{2}$ spatial pixels for three provinces in the Eastern Black Sea region (Artvin, Rize and Trabzon). Cosmic ray-induced annual effective dose calculations were performed based on latitude and altitude changes with EXPACS, an excel-based program. Besides, the effect of cosmic radiation on the population living in the study area was determined. For the entire study area, it was calculated the average effective dose rate from Cosmic radiation as $0.65 \mathrm{mSv} y^{-1}$ and range as (0.33-1.72) $\mathrm{mSv}$ $y^{-1}$. The average annual collective effective dose rate was determined approximately 508 person-Sv $y^{-1}$. Besides, the population-weighted average annual effective dose rates were obtained as $449 \mu S v y^{-1}, 376 \mu S v y^{-1}$ and $370 \mu S v y^{-1}$ for Artvin, Rize and Trabzon provinces, respectively.
\end{abstract}

Keywords: Annual effective dose rate, Cosmic radiation, Eastern Black Sea Region, Mapping

\section{Doğu Karadeniz Bölgesinde kozmik ışın kaynaklı yıllık etkin doz dağılımının belirlenmesi}

\begin{abstract}
Özet. Bu çalışmada doğal radyasyonun önemli bir kısmını oluşturan kozmik ışın kaynaklı yıllık etkin doz hızı dağılımı, Doğu Karadeniz Bölgesindeki üç il için (Artvin, Rize ve Trabzon) 200×200m² 'lik mekânsal çözünürlükte haritalandırılmıştır. Kozmik ışın kaynaklı yıllık etkin doz oranı hesaplamaları, Excel tabanlı çalışan bir program olan EXPACS ile enlem ve rakım değişimlerine bağlı olarak gerçekleştirilmiştir. Ayrıca çalışma alanında yaşayan nüfusun kozmik radyasyondan etkilenme seviyeleri de tespit edilmiştir. Çalışma alanının tamam için, Kozmik ışından kaynaklanan yılık etkin doz oranının ortalaması $0.65 m S v y^{-1}$ ve değişim aralığı (0.33-1.72) $m S v y^{-1}$ olarak hesaplanmıştır. Çalışma alanının geneli için yıllık kollektif etkin doz hızı ise yaklaşı 508 insan-Sv $y^{-1}$ olarak belirlenmiştir. Ayrıca kozmik radyasyondan kaynaklanan kişi başı yılık etkin doz, sırasıyla Artvin, Rize ve Trabzon için $449 \mu S v y^{-1}, 376 \mu S v y^{-1}$ ve $370 \mu S v y^{-1}$ olarak tespit edilmiştir.
\end{abstract}

Anahtar Kelimeler: Yıllık etkin doz hızı, Kozmik radyasyon, Doğu Karadeniz Bölgesi, Haritalama

\section{INTRODUCTION}

People are constantly exposed to natural radiation sources throughout their lives. These natural radiation sources are evaluated under two main groups [1]. The first group is terrestrial radionuclide induced radiation connected to geological rock structures. The second group is cosmic radiation from extraterrestrial sources. Approximate $14 \%$ of the annual effective dose is caused by Cosmic radiation $[2,3]$. The large amount of cosmic rays are stopped by the atmosphere before it reaches the ground. Cosmic 
rays that can pass through the atmosphere have significant effects in areas above sea level [4]. The effective dose due to cosmic ray exposure averaged over the world's population was assessed to be 0.38 $m S v y^{-1}[2]$.

Cosmic radiation is an ionizing radiation produced by the collision of atoms in the Earth's atmosphere with extraterrestrial photons and $\alpha$ particles [5]. In addition, charged particles released from solar flares are an important source of cosmic radiation. [6].

The effect of the cosmic ray increases with the increase of latitude and altitude [7]. Due to the geomagnetic latitude effect, it has been reported that the dose rate of Cosmic radiation increases at higher latitudes (in Arctic), while the dose rate decreases at lower latitudes (in Equator) [4]. The earth's magnetic field shows a shield effect against cosmic rays. In addition, the increase in altitude causes the components of the dose equivalent from Cosmic radiation to change [2]. The greatest contribution to the equivalent dose at the sea level comes from muon, but due to the increase in height, the neutrons, protons, photons, electrons and positrons also take into account the dose rate caused by the Cosmic ray [8]. The direct dependence of the cosmic rays on both latitude and altitude has led to the exploration of new approaches in the prediction of cosmic ray-induced dose distribution. One of the studies in recent years is PARMA/EXPACS model which was created by Sato et al.[4,9-11]. EXPACS (EXcel-based Program for calculating Atmospheric Cosmic-ray Spectrum) is a sophisticated model for calculating cosmic ray doses, taking into account factors such as latitude, longitude, altitude, solar activity, atmospheric depth and cut-off rigidity [12]. It is based on the PARMA model (PHITS based Analytical Radiation Model in the Atmosphere) $[4,10]$

In recent years, many studies have been conducted to determine the efective dose distribution caused by cosmic radiation. Cinelli et al. [13] calculated the cosmic ray-induced effective dose rate for the whole of Europe based on the height factor and created a distribution map. Sato et al. [14] mapped the effective dose distribution of population-weighted cosmic radiation from the entire world with the EXPACS model. In both studies, local changes could not be determined with appropriate sensitivity due to the calculation of very large areas.

The purpose of this study is to create a map of cosmic radiation dose distribution for the eastern Black Sea region where have most rugged terrain of Turkey, and to determine the total dose values which is exposure of the population living in this region. Thus, it is aimed to define some of the previously obtained global results in a more detailed way.

\section{MATERIAL AND METHOD}

\subsection{Study Area}

The study area is the three provinces (Artvin, Rize and Trabzon) in the eastern Black Sea Region of Turkey. Figure 1a shows the study area. These provinces represent an important part of the Eastern Black Sea Region in terms of population and surface area. The average altitude of the study area is approximately $800 \mathrm{~m}$ for Trabzon and Rize, and about $1600 \mathrm{~m}$ for Artvin [15]. Elevation changes are in the range of (03700) $m$ for Artvin, (0-3200) $m$ for Trabzon and (0-3400) $m$ for Rize. These rapid elevation changes lead to sudden changes in cosmic radiation dose. In addition, the intense solar radiation effect at high locations increases the Cosmic Ray Fluxes [16].

Figure $1 b$ shows the population distribution map for the study area in 2018 [17]. This map was created by estimating population values for $100 \times 100 \mathrm{~m}^{2}$ regular grid (1 pixel) with random forest machine learning algorithm [18]. Moreover, Each pixel in the present study area was updated with current population 
information provided by Turkey Statistical Institute [19], and this level of resolution $\left(100 \times 100 \mathrm{~m}^{2}\right.$ cells $)$ was decreased to $200 \times 200 \mathrm{~m}^{2}$.

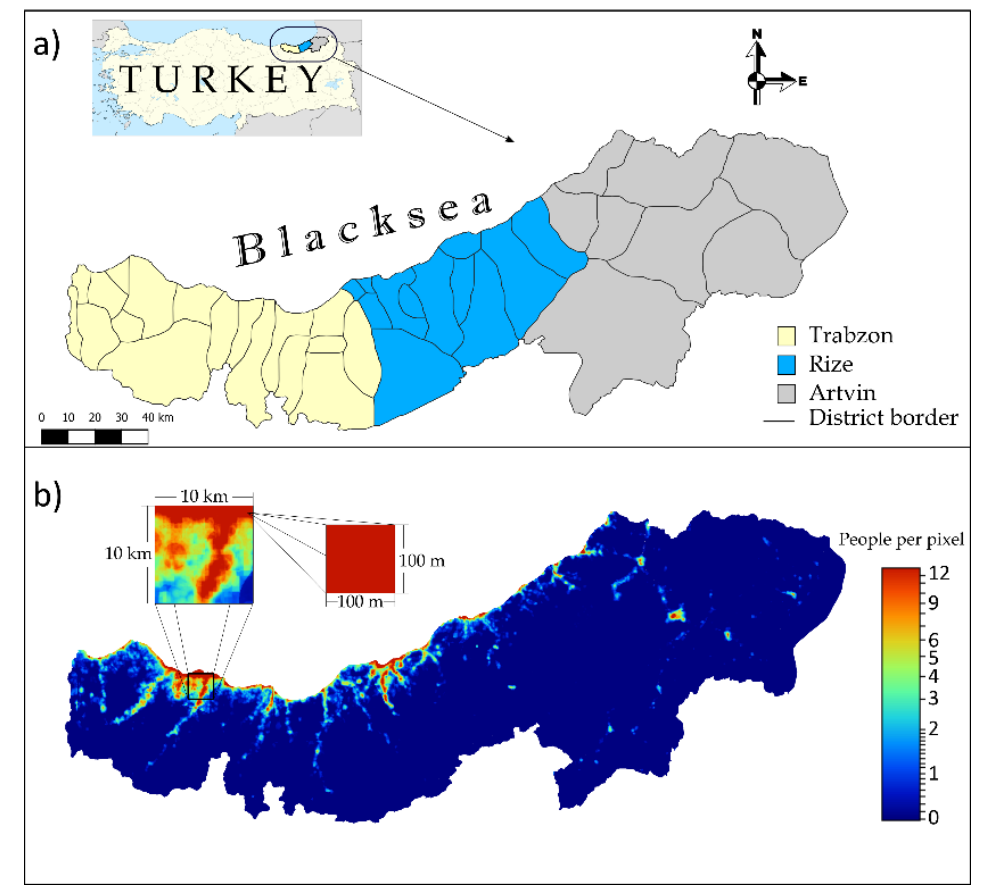

Figure 1. a) Study area, b) Population distribution map determined by $100 \times 100 \mathrm{~m}^{2}$ pixel for study area [17].

\subsection{Dose Calculation}

The dose calculations in this study were calculated with EXPACS (EXcel-based Program for calculating Atmospheric Cosmic-ray Spectrum) [4,9,12]. This program is based on the PARMA model [9] which is named PHITS (Particle and Heavy Ion Transport code System) -based Analytical Radiation Model in the Atmosphere (PARMA) [10,11]. EXPACS model can calculate terrestrial cosmic ray fluxes of protons, neutrons, muons, electrons, positrons, ions with charge up to $28(\mathrm{Ni})$ and photons nearly in the Earth's atmosphere. it can also calculate the effective dose from the obtained cosmic ray fluxes [12].

\subsection{Components of Cosmic Radiation}

Typically, Cosmic rays are examined as primary and secondary cosmic rays. The primary cosmic rays are very high energy cosmic rays that reach the earth directly. They consist of protons (87\%), particles (11\%), nuclei with low atomic numbers (1\%) and high-energy electrons (1\%) [20]. Secondary cosmic rays are formed by the collision with gas atoms in the atmosphere of primary cosmic rays. The energy of such rays is lower than the primary cosmic rays. Secondary cosmic rays are divided into two classes as the directly and indirectly ionizing component [21]. Directly ionizing components of cosmic radiation are two class as muonic component (muons) and electromagnetic component (photons. electrons and positrons). Indirectly ionizing components of cosmic radiation are neutrons and protons [22]. Although muons constitute the most important component at sea level of the effective dose rate from secondary cosmic rays, neutrons, electrons, photons, positrons and protons also affect the effective dose rate with the increase in altitude [8].

\subsection{Software Sources}

All analyzes and calculations in this study were performed by R programming [23]. All maps used and prepared in the study were created with Quantum Geographic Information System (QGIS) version 2.18.23 
[24]. In addition, regular grid analysis and estimation data were combined with SAGA-GIS version 2.3.2 [25].

\section{RESULTS AND DISCUSSIONS}

\subsection{Mapping of Cosmic Ray Dose}

All the study area was defined by a regular grid area of $200 \times 200 \mathrm{~m}^{2}$ pixels. Figure 2 shows the structure of the regular grid created for this study. Each pixel in this regular grid was represented by latitude, longitude, altitude and population information. In particular, by taking into account the latitude and altitude effects, it was calculated with the EXPACS model the effective dose rate from the cosmic ray for each grid pixel. Later, all results obtained were indicated by a color scale and mapped. In Figure 3 shows the cosmic ray-induced annual effective dose rate distribution map and statistical summary values for all the study area. According to the results, it was determined that Artvin is affected by cosmic rays more than Rize and Trabzon. The main reason for this is thought to be due to high altitude areas in Artvin province. For the overall study area, the mean and range of the effective annual dose from Cosmic radiation was calculated $0.65 m S v y^{-1}$ and (0.33-1.72) $m S v y^{-1}$, respectively. According to the UNSCEAR report, the average annual dose from Cosmic radiation is approximately $0.46 \mathrm{mSv}^{-1}$ (the directly ionizing and photon component the average value is $0.34 \mathrm{mSv} \mathrm{y}^{-1}$ and the neutron component, the average value is $12 \mathrm{mSv}^{-1}$ ) [2]. In addition, the study conducted by Cinelli et al. reported that the annual average effective dose rate from Cosmic radiation was about $0.39 \mathrm{mSv}^{-1}$ for the whole of Europe [13] . The average annual effective dose rate obtained from the study was found to be higher than in Europe and the world averages.

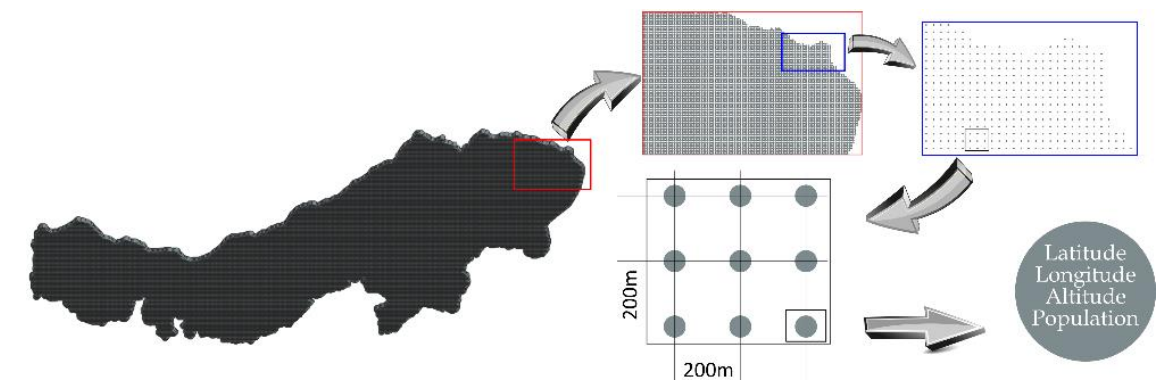

Figure 2. Grid structure of study area

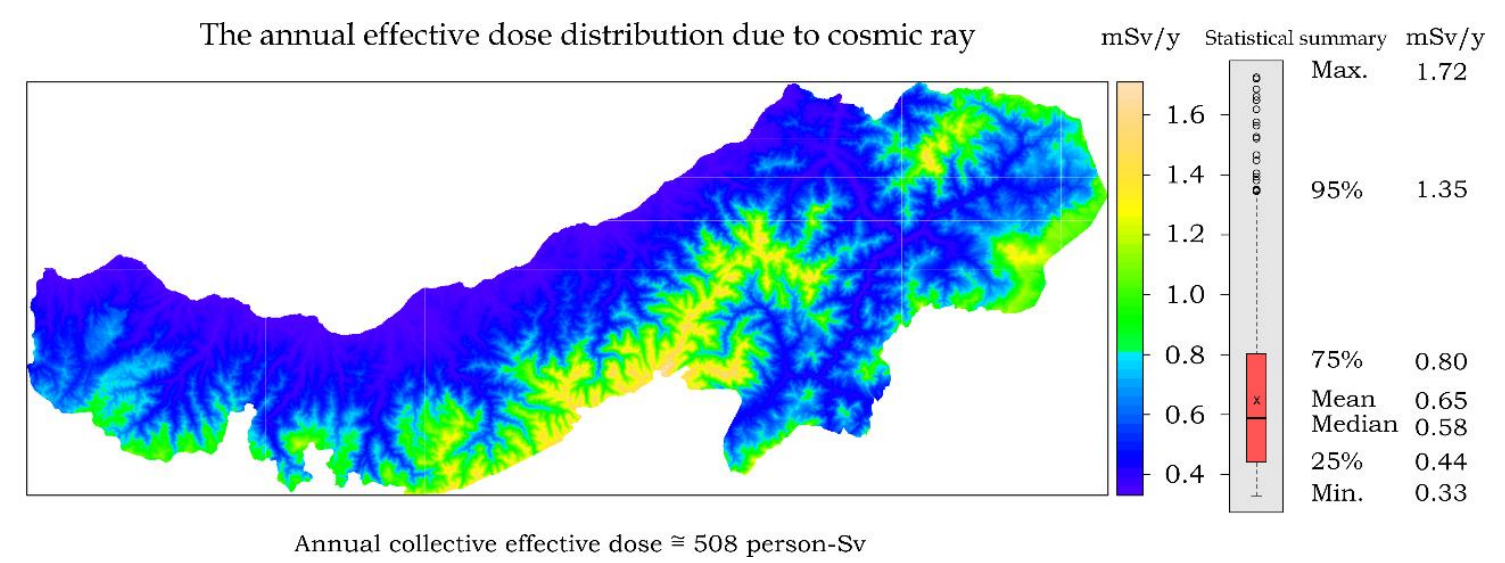

Figure 3. Distribution map of annual effective dose rate from cosmic radiation for study area

\subsection{Determination of Population Exposure}

Based on the total population data of the study area for 2018, Annual cosmic-ray collective effective dose was determined to be approximately 508 person-Sv $y^{-1}$. The collective dose was calculated for each grid 
node $\left(200 \times 200 \mathrm{~m}^{2}\right)$ by multiplying the annual effective dose value with the number of population per pixel. This calculated dose rate is higher than European countries such as Estonia (400 person-Sv $y^{-1}$ ), Montenegro (200 person-Sv $y^{-1}$ ), Luxembourg (200 person-Sv $y^{-1}$ ) ve Iceland (200 person-Sv $\left.y^{-1}\right)$ [13]. Figure 4 show Annual collective effective dose (person-Sv $y^{-1}$ ) and the average annual effective dose per capita $\left(\mu S v y^{-1}\right)$ due to cosmic rays for each province in the study area. The annual collective effective dose rate vary depending on the population of the provinces and have been calculated as 79 person-Sv $y^{-}$ ${ }^{1}, 135$ person-Sv $y^{-1}$ and 295 person-Sv $y^{-1}$ for Artvin, Rize and Trabzon, respectively. In addition, average the population-weighted (per person) annual effective dose rate due to cosmic radiation was computed as $449 \mu S v y^{-1}$ for Artvin, $376 \mu S v y^{-1}$ for Rize and $370 \mu S v y^{-1}$ for Trabzon. In only Artvin was determined a value above the world mean value $\left(390 \mu S v y^{-1}\right)$ of per person annual effective dose rate reported by UNSCEAR [2]. In addition, the average effective dose per capita for the whole study area was calculated $382 \mu S v y^{-1}$. This dose rate are quite close to the per capita average annual effective dose of Turkey (about $\left.400 \mu S v y^{-1}\right)[13]$.

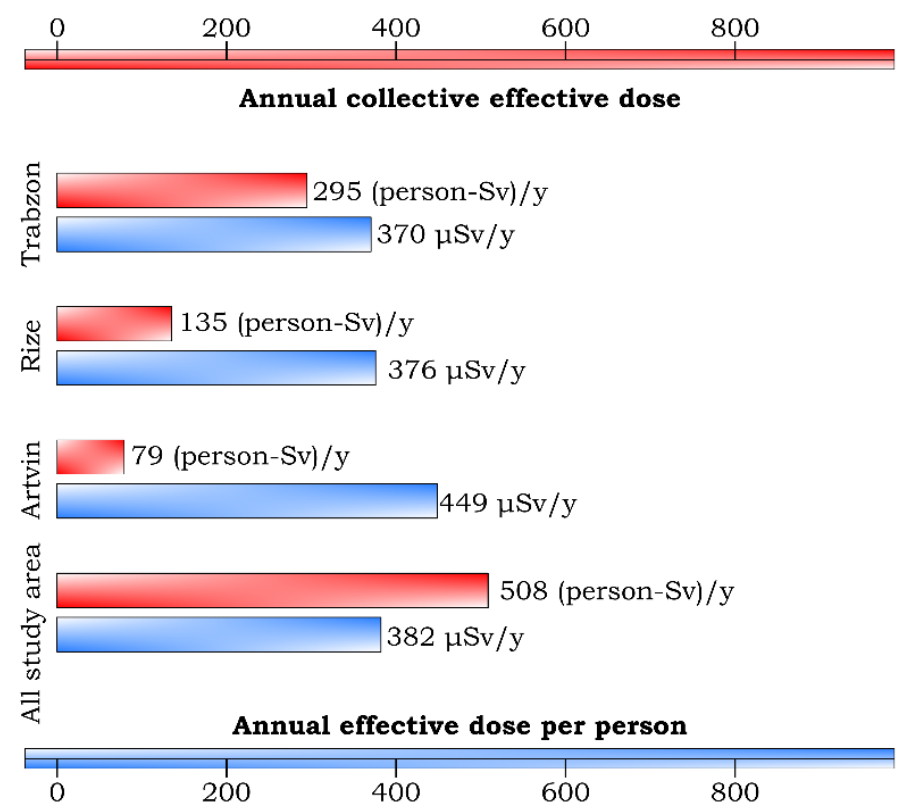

Figure 4. Annual collective effective dose (person-Sv $\left.y^{-1}\right)$ and the average annual effective dose per person $\left(\mu S v y^{-1}\right)$ due to cosmic rays for each province in the study area.

\section{CONCLUSION}

In this study, the effective dose rate distribution due to cosmic radiation in the Eastern Black Sea Region of Turkey was mapped and the effect levels from this cosmic rays of the population were determined. The maps were created in $200 \times 200 \mathrm{~m}^{2}$ pixels and latitude, longitude, altitude and population information were defined in each pixel. Dose calculations were calculated with EXPACS, which is an Excel-based program based on the PARMA model. The dose calculations were separately performed for each pixel, and then the annual effective dose rate distributions were mapped by representing the calculated results on a color scale. At the end of the study, the mean and range of the annual effective dose rate due to cosmic radiation was computed $0.65 m S v y^{-1}$ and $(0.33-1.72) m S v y^{-1}$, respectively. The average annual collective effective dose rate and the population-weighted average annual effective dose rate were obtained 79 person-Sv $y^{-1}$ and $449 \mu S v y^{-1}$ for Artvin, 135 person-Sv $y^{-1}$ and $376 \mu S v y^{-1}$ for Rize and 295 person-Sv $y^{-1}$ and $370 \mu S v y^{-1}$ for Trabzon. In addition, the average annual per capita effective dose for all the study area was calculated as $382 \mu S v y^{-1}$ closely to average of Turkey (about $400 \mu S v y^{-1}$ ). 


\section{REFERENCES}

[1] Yeşilkanat C.M., Kobya Y., Taskin H., Çevik U., Dose rate estimates and spatial interpolation maps of outdoor gamma dose rate with geostatistical methods; A case study from Artvin, Turkey, J. Environ. Radioact. 150 (2015) 132-144. doi:10.1016/j.jenvrad.2015.08.011.

[2] UNSCEAR, Source and effects of ionizing radiation, United Nations Scientific Committee on the Effects of Atomic Radiation, Report to the General Assembly with Annex B, United Nations, New York, 2000.

[3] Zeyrek C.T., İyonize Radyasyon Uygulamaları İçin Güvenlik ve Korunmaya Yönelik Genel Kavramlar. (In Turkish), Süleyman Demirel Üniversitesi Fen Bilim. Enstitüsü Derg. 17 (2013) 19.

[4] Sato T., Analytical model for estimating the zenith angle dependence of terrestrial cosmic ray fluxes, PLoS One. 11 (2016) 1-22. doi:10.1371/journal.pone.0160390.

[5] Bagshaw M., Illig P., The Aircraft Cabin Environment, Fourth Edi, Elsevier Inc., 2018. doi:10.1016/b978-0-323-54696-6.00047-1.

[6] Wilson B.G., Nehra C.P., Cosmic Ray Increases Associated with Solar Flares, J. Phys. Soc. Japan Suppl. 17 (1962) 269. https://ui.adsabs.harvard.edu/abs/1962JPSJS..17B.269W/abstract (accessed July 5, 2019).

[7] Neher H. V., Cosmic rays at high latitudes and altitudes covering four solar maxima, J. Geophys. Res. 76 (1971) 1637-1651. doi:10.1029/JA076i007p01637.

[8] O’Brien K., Friedberg W., Sauer H.H., Smart D.F., Atmospheric cosmic rays and solar energetic particles at aircraft altitudes., Environ. Int. 22 (1996) 9-44. http://www.ncbi.nlm.nih.gov/pubmed/11542509.

[9] Sato T., Analytical model for estimating terrestrial cosmic ray fluxes nearly anytime and anywhere in the world: Extension of PARMA/EXPACS, PLoS One. 10 (2015) 1-33. doi:10.1371/journal.pone.0144679.

[10] Sato T., Niita K., Matsuda N., Hashimoto S., Iwamoto Y., Noda S., Ogawa T., Iwase H., Nakashima H., Fukahori T., Okumura K., Kai T., S. Chiba, T. Furuta, L. Sihver, Particle and heavy ion transport code system, PHITS, version 2.52, J. Nucl. Sci. Technol. 50 (2013) 913-923. doi:10.1080/00223131.2013.814553.

[11] Sato T., Niita K., Matsuda N., Hashimoto S., Iwamoto Y., Furuta T., Noda S., Ogawa T., Iwase H., Nakashima,H., Fukahori T., Okumura K., Kai T., Chiba S., Sihver L., Overview of particle and heavy ion transport code system PHITS, Ann. Nucl. Energy. 82 (2015) 110-115. doi:10.1016/J.ANUCENE.2014.08.023.

[12] EXPACS, EXcel-based Program for calculating Atmospheric Cosmic-ray Spectrum (EXPACS),URL: https://phits.jaea.go.jp/expacs/, (2016). 
[13] Cinelli G., Gruber V., De Felice L., Bossew P., Hernandez-Ceballos M.A., Tollefsen T., Mundigl S., De Cort M., European annual cosmic-ray dose: Estimation of population exposure, J. Maps. 13 (2017) 812-821. doi:10.1080/17445647.2017.1384934.

[14] Sato T., Evaluation of world population-weighted effective dose due to cosmic ray exposure, Sci. Rep. 6 (2016) 6-12. doi:10.1038/srep33932.

[15] USGS, Digital elevation maps (DEM) data sets, http://earthexplorer.usgs.gov/ (Available date: 11.01.2015), (2013). http://earthexplorer.usgs.gov/.

[16] YEGM, Yenilenebilier Enerji Genel Müdrlüğü (YEGM), Tükiye Güneş Enerjisi Potansiyel Atlası (GEPA), URL: http://www.yegm.gov.tr/MyCalculator/, (2019).

[17] WorldPop, WorldPop (www.worldpop.org) and Center for International Earth Science Information Network (CIESIN), Columbia University, (2018). doi:https://dx.doi.org/10.5258/SOTON/WP00645.

[18] Stevens F.R., Gaughan A.E., Linard C., Tatem A.J., Disaggregating census data for population mapping using Random forests with remotely-sensed and ancillary data, PLoS One. 10 (2015) 122. doi:10.1371/journal.pone.0107042.

[19] Turkish Statistical Institute (TurkStat), Population Statistics, URL: http://www.turkstat.gov.tr/UstMenu.do?metod=temelist. Date Accessed: 14.02.2019, (2019).

[20] Eisenbud M., Gesell T., Enviromental Radioactivity, 4. edition, Academic Press, 1997.

[21] Rasolonjatovo D.A.H., Suzuki H., Hirabayashi N., Nunomiya T., Nakamura T., Nakao N., Measurement for the dose-rates of the cosmic-ray components on the ground., J. Radiat. Res. 43 Suppl (2002) S27-33. doi:10.1269/jrr.43.s27.

[22] Schlickeiser R., Direct Observations of Cosmic Rays, in: 2002: pp. 25-71. doi:10.1007/978-3-66204814-6_3.

[23] Ihaka R., Gentleman R., R: A Language for Data Analysis and Graphics, J. Comput. Graph. Stat. 5 (1996) 299-314. doi:10.1080/10618600.1996.10474713.

[24] Quantum GIS Development Team, Quantum GIS Geographic Information System. Open Source Geospatial Foundation Project, (2018). https://qgis.org/en/site/index.html (date accessed: 10.12.2018).

[25] Böhner J., Bock M., Wichmann V., Fischer E., Wehberg J., Conrad O., Bechtel B., Dietrich H., Gerlitz L., System for Automated Geoscientific Analyses (SAGA) v. 2.1.4, Geosci. Model Dev. 8 (2015) 1991-2007. doi:10.5194/gmd-8-1991-2015. 